Copyright (C) 2014 by Academic Publishing House Researcher

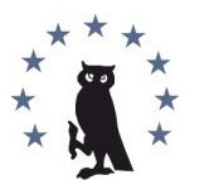

Published in the Russian Federation

European Researcher

Has been issued since 2010.

ISSN 2219-8229

E-ISSN 2224-0136

Vol. 81, No. 8-2, pp. 1523-1531, 2014

DOI: $10.13187 / \mathrm{er} .2014 .81 .1523$

www.erjournal.ru

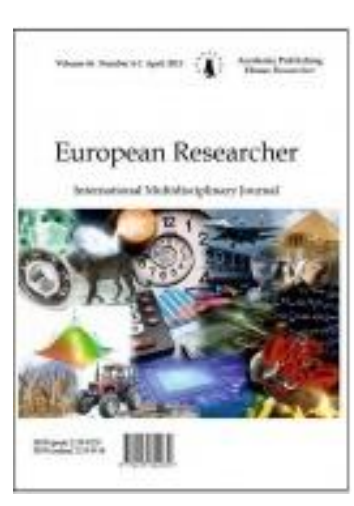

\title{
Consumer Attitude Toward Mobile Marketing in Bosnia and Herzegovina
}

\author{
${ }^{1}$ Irma Jasarspahic \\ 2 Teoman Duman \\ 1-2 International Burch University, Bosnia and Herzegovina \\ 1 E-mail: irmica-j@hotmail.com \\ 2E-mail: teoman.duman@ibu.edu.ba
}

\begin{abstract}
Driven by the ongoing evolution in mobile technologies and the increasing popularity of the internet, the mobile marketing is becoming more and more popular to marketers whose aim is definitely to promote their goods and services to the consumer. Since many people are still unaware of the potential of marketing via mobile devices this research aimed to examine factors based on content of mobile marketing (entertainment, information, irritation, utility and personalization) and frequency factor that are affecting the formation of attitude toward mobile marketing targeting $\mathrm{BH}$ consumers, and also will try bring to light the response behavior of consumers attitude toward mobile marketing practices and how consumers perceive mobile marketing in $\mathrm{BH}$.

The research approach for this study is descriptive and the data was collected by 200 online surveys from young population of BH. The data was analyzed using the software program SPSS. Based on analysis and findings, variables of content have different effect on consumer attitude. Research has shown that a lot of respondents believe mobile marketing is a good idea and that they certainly eases the need for products and services. This paper could be used as a good basis for future research on bigger sample.
\end{abstract}

Keywords: Mobile marketing; Consumer Attitude; Response Behavior; Survey; SPSS.

\section{Introduction}

Considering the huge increase in the popularity of mobile technology and the internet, mobile phones and tablets will be more important advertising screens than the traditional $T V$. New mobile technology has a very important impact on today's businesses. Just the fact that the mobile phone is always with its owner is very important from the perspective of advertisers and brands that surround us. Due to this fact marketing experts invented the term "mobile marketing".

Common definition states that Mobile marketing is simply the process of marketing to people via their mobile devices. Using their mobile phones people are often faced with different forms of mobile marketing: SMS and MMS marketing campaigns (promotional bulk), SMS prize games, SMS quizzes, print or packaging of products that have QR code, examples of branded mobile applications that are developed for the needs of local promotions, mobile banking, huge number of popular mobile applications, etc. Mobile marketing is becoming interesting to the 
companies that have started to use SMS marketing to promote their products and services. Thus, personal nature of the mobile phones accelerated the usage rate of SMS and MMS as a marketing channel (Taylor, 2008).

According to the data of Agency for Statistics of $\mathrm{BH}$, number of mobile phone users in $\mathrm{BH}$ is increasing every year, and some households have five and more mobile phones (bhas, 2014). Although mobile marketing has enormous potential and it is one of the fastest growing new advertising tactics, there is still lot to learn about it in $\mathrm{BH}$ context. The purpose of this study is to examine factors that are affecting the formation of attitude toward mobile marketing targeting $\mathrm{BH}$ consumers.

\section{Literature review}

In order to support this research it is important to deliver relevant literature of earlier studies about mobile marketing and attitudes towards it.

Roach (2009) tried to examine how a consumer's perception of the relative advantages, compatibility and complexity associated with mobile phone marketing, and their involvement with their mobile phone, influenced their intention to accept mobile marketing. She used a deductive, quantitative research approach for her study, and the data was collected using questionnaire administered to a sample of 254 university students. Findings showed that a consumer's perceptions of two of the three innovation attributes tested (relative advantage and compatibility) were significantly associated with their acceptance (or adoption) of marketing messages sent via their mobile phone.

Parreño (2013) analyzed key drivers of teenagers' attitude toward mobile advertising and its effects on teenagers' mobile advertising acceptance. As an approach to his research he used proposed model of affective (irritation and entertainment) and cognitive (perceived usefulness) factors that influence on the attitude toward mobile advertising and its acceptance. Findings showed that entertainment, irritation and usefulness are key drivers of teenagers' attitude toward mobile advertising. Moreover, perceived usefulness reduces irritation.

Gao (2010) examined factors affecting consumers' acceptance of mobile marketing in China. As a research method authors used technology acceptance, uses and gratifications theories to develop a conceptual model of antecedent factors (including risk acceptance related to the mobile platform and personal attachment related to mobile devices); marketing-related mobile activity; and acceptance of mobile marketing practice. The results showed that the importance of risk acceptance and personal attachment led to greater mobile marketing acceptance, and support the "priming" effect of regular mobile phone usage on orienting consumers toward accepting mobile marketing initiatives.

Smutkupt (2012) investigated the impact of SMS (Short Message Service) advertising on consumer perceptions of Au Bon Pain's brand equity in Thailand. As methodology they developed a 4x2 between-subjects method, with four levels of message types (personalization, interactivity, general, and no message control) and two levels of permission (with and without permission). Then three message types (i.e. personalized, interactive, and general ads) were send to the participants, who were first split into two groups on the basis of their willingness to receive messages from the tested brand: permission group and non-permission group. The results indicated that SMS marketing has a significant positive impact on brand awareness and perceived quality.

Persuad and Azhar (2012) in their study investigated consumers' willingness to accept marketing through their smartphones. They collected data by self-administered web-based surveys of 428 respondents from Canada. The survey contained questions about respondents' mobile phone usage behavior and their perceptions of, and intention to, participate in mobile marketing. The results indicated that consumers' shopping style, brand trust, and value are key motivations for engaging in mobile marketing through their smartphones.

Jayawardhena (2009) aimed to develop a conceptual model to examine the influence of four antecedent factors (personal trust, institutional trust, perceived control and experience) on consumers' willingness to participate in permission-based mobile marketing. Data is collected from surveys of consumers in Finland, Germany and the UK. He found out that the main factor affecting the consumers' decision to participate in mobile marketing is institutional trust, while the influence of other antecedent factors are less pronounced. Altogether, it is found that the more experienced 
consumers become with mobile marketing, the less influence perceived control will have on permission.

\section{Research questions/ hypothesis}

The purpose of this study is to determine the attitudes of young population toward Mobile Marketing in Bosnia and Herzegovina and to discover the relationships of customer attitudes with their response behavior. Variables are created from previous theories and models, and combined in order to research main problem of the study. Therefore; hypotheses are formulated to analyze further if consumer form a positive or negative attitude when content is considered: practices.

H1: Entertainment is positively correlated with overall attitude towards Mobile marketing practices

H2: Information is positively correlated with overall attitude towards Mobile marketing

H3: Irritation is negatively correlated with overall attitude towards Mobile marketing practices

H4: Utility is positively correlated with overall attitude towards Mobile marketing practices

H5: Personalization is is positively correlated with overall attitude towards Mobile marketing practices

H6: Frequency of receiving mobile ad is negatively correlated with overall attitude towards Mobile marketing practices

The following research questions are determined:

R.Q.1: What are the main personal factors that affect consumers attitude toward Mobile Marketing?

R.Q.2: What is the overall attitude toward mobile marketing among respondents in Bosnia and Herzegovina (positive or negative)?

Since this study will try to bring to light the response behavior of consumers attitude toward mobile marketing practices in $\mathrm{BH}$, the next research question is formulized:

R.Q.3: How the consumers' attitude toward mobile marketing correlate with the consumers' response behavior (e.g., purchase intentions) of Mobile Marketing?

\section{Research methodology}

The survey was collected through Google docs, afterwards the data was exported to Microsoft Excel. Total sum of 200 surveys was completed on April $30^{\text {th }}$. The data was checked for completeness and 23 respondents were deleted from table because of the unfamiliarity with Mobile Marketing. Respondent were ask to answer the questions based on their experience with Mobile Marketing by evaluating statements using the Likert Scale from 1-5 where 1 represents (strongly disagree) and 5 represents (strongly agree) while 3 represent (neutral) for those who didn't have any opinion about this.

Based on the completed surveys, researcher identified customer attitudes for mobile advertising, and the results of the survey dealt in the software program SPSS (Statistical Package for the Social Sciences), which has helped me to establish and carry out an analysis of customers attitudes, and to set priorities thereof. The frequency analyses of demographic questions in the questionnaire were examined. The attitude questions in the questionnaire were examined with descriptive analyses, reliability and regression analyses.

\section{Conceptual framework}

The research is focusing on different factors that affecting consumer attitude toward mobile marketing. Basic purpose of this research is to understand the effect of each factor on consumer attitude toward mobile marketing, whether positive or negative. The folowing figure 1 presents accepted and applied model. 


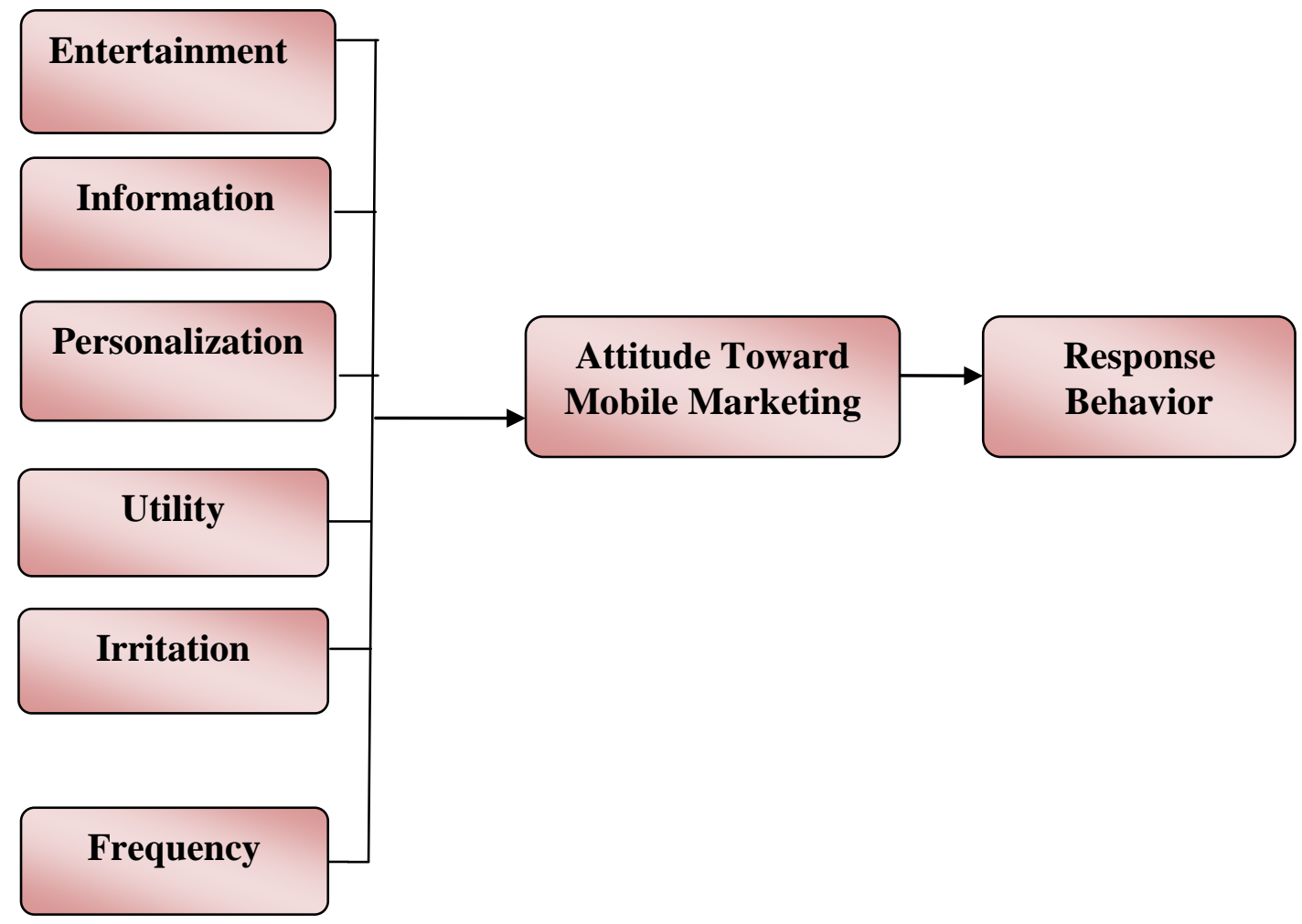

Figure 1: The Model

The value of entertainment lies within the ability to fulfill the consumers' needs for escapism, diversion, aesthetic enjoyment or emotional release. According to Haghirian (2005), the perceived entertainment of mobile advertising is not only related to attitude, but also adds perceived value of the advertisement by customer.

Advertisement informativity has been defined by Mackenzie (1989) as "the extent to which the consumer perceives claims made about the brand in the advertisement to be truthful and believable". Ad informativity is defined as the extent to which the consumer perceives claims made about the brand in the ad to be truthful and believable, and perceive the source to have knowledge and skills, and to give truthful and unbiased information.

A variable that has not been subjected to a lot of empirical research is personalization, where messages are catered to fit the individual and offer individualized content. Without personalization, mobile advertising is nothing more than impersonalized mass messaging, that may be neither informative nor entertaining to the receiver and can result in a negative attitude towards the advertisement (Bauer, Reichardt, Barnes and Neumann, 2005).

The utility concept is a basic constituent of relationship marketing, the ability to provide superior value to customers is a prerequisite when trying to establish and maintain long-term customer relationships. A value can be described as an enduring belief that a specific conduct or state is personally-psychologically or socially-culturally preferable to a converse mode of conduct or an opposite end state of existence (Levi, 1990).

Irritation in advertising can be defined as an advertisement that generates annoyance, discontent, and brief intolerance. Tsang assert that perceived irritation of mobile advertising has impact on consumers' attitude toward mobile advertising. When advertising is intrusive, it will result in irritation, which in turn will have a negative effect upon the attitude and influence on the consumer's behavior. Irritation can also cause that the persuasive power of the ad is reduced.

There are arguments about personalization and frequency of receiving mobile ads. Robins (2003) argued that consumers would like the content of mobile services to be customized to their interests and relevant for them. Personalization of mobile marketing can enable marketers to reach their potential customers in a very individual way and thus increase the relationship with the 
consumers. However other research argued that Frequency of exposure to the mobile marketing affect customers attitude towards this type of advertisement (Ducoffe, 1995).

\section{Results}

One of the today's most popular reliability statistics in use is Cronbach's alpha (Cronbach, 1951). It determines the internal consistency or average correlation of items in a survey instrument to measure its reliability. Alpha coefficient ranges in value $0-1$ and it can be used to describe the reliability of factors extracted from questionnaires or scales. Nunnaly (1978) has indicated 0.7 to be an acceptable reliability coefficient but lower thresholds are sometimes used in the literature.

Cronbach Alpha is higher than 0.7 for all tested items, so it means that this scale can be evaluated as reliable. The following step is to determine correlation values among independent variables in the research model. Correlation analysis is used to test the degree of association between variables. The arithmetic means, standard deviation and correlation values of the factors are presented in Table 1.

Table 1: Correlation Analyses

\begin{tabular}{|c|c|c|c|c|c|c|c|c|c|}
\hline Factors & AA & SS & $\mathbf{1}$ & $\mathbf{2}$ & $\mathbf{3}$ & $\mathbf{4}$ & $\mathbf{5}$ & $\mathbf{6}$ & $\mathbf{7}$ \\
\hline Frequency & 3.06 & 0.89 & $\mathbf{1}$ & -.321 & -.448 & -.270 & -.523 & -.381 & -.296 \\
\hline Entertainment & 3.85 & 1.04 & & $\mathbf{1}$ & .583 & .019 & .530 & .395 & .540 \\
\hline Information & 3.49 & 1.09 & & & $\mathbf{1}$ & -.054 & .496 & .398 & .575 \\
\hline Irritation & 4.25 & 0.98 & & & & $\mathbf{1}$ & -.011 & .032 & -.054 \\
\hline Utility & 3.66 & 1.10 & & & & & $\mathbf{1}$ & .400 & .531 \\
\hline Personalization & 3.67 & 1.01 & & & & & & $\mathbf{1}$ & .374 \\
\hline General Attitude & 3.40 & 1.11 & & & & & & & $\mathbf{1}$ \\
\hline
\end{tabular}

Multiple regression is an extension of simple linear regression. It is used when we want to predict the value of a variable based on the value of two or more other variables. As shown in research model, independent variables are entertainment, information, irritation, utility, personalization and frequency of receiving ads. So, in the first stage of multiple regression analyses, the relationships between variables were examined including dependent variables and independent variables. In this stage, researcher tested hypothesis.

In statistics, standardized coefficients or beta coefficients are the estimates resulting from an analysis performed on variables that have been standardized so that they have variances of 1 . This is usually done to answer the question of which of the independent variables have a greater effect on the dependent variable in a multiple regression analysis, when the variables are measured in different units of measurement. The p-values in the following tables will show the significance level of the variables. Variance inflation factor (VIF) show whether the high correlation in the relationship between variables causes a problem or not.

Table 2: Multiple Regression Analysis Related to Entertainment toward Attitude

\begin{tabular}{|c|c|c|c|c|c|c|}
\hline \multirow{2}{*}{ Model } & \multicolumn{2}{|c|}{$\begin{array}{c}\text { Unstandardized } \\
\text { Coefficients }\end{array}$} & $\begin{array}{c}\text { Standardize } \\
\text { d } \\
\text { Coefficients }\end{array}$ & \multirow{2}{*}{ t } & Sig. & VIF \\
\cline { 2 - 7 } & B & Std.Error & Beta & & \\
\hline Entertainment & .618 & .183 & & 3.373 & & \\
\hline
\end{tabular}

As it can be seen from the table above, both variables significantly influence the general attitude toward mobile marketing in 0.05 significance level. There is a strong relationship $(\mathrm{p}=.000)$ between dependent variable and Entertainment. The second independent variable that has been used to predict the value of our dependent variable is Information. The corresponding hypothesis is Information is positively correlated with overall attitude towards Mobile marketing. 
Table 3: Multiple Regression Analysis Related to Information toward Attitude

\begin{tabular}{|c|c|c|c|c|c|c|}
\hline \multirow{2}{*}{ Model } & \multicolumn{2}{|c|}{$\begin{array}{c}\text { Unstandardized } \\
\text { Coefficients }\end{array}$} & $\begin{array}{c}\text { Standardized } \\
\text { Coefficients }\end{array}$ & \multirow{2}{*}{ t } & Sig. & VIF \\
\cline { 2 - 6 } & $\mathrm{B}$ & Std.Error & Beta & & & \\
\hline (Constant) & .770 & .153 & & 5.031 & .000 & \\
\hline Information & .230 & .049 & .352 & 4.681 & .000 & 1.678 \\
\hline
\end{tabular}

The following table presents data related to Irritation. It is important to point out that two statements that were measuring this factor had negative connotation, so in this case we will have reverse situation (high numbers present negative and low numbers present positive attitudes).

Table 4: Multiple Regression Analysis Related to Irritation toward Attitude

\begin{tabular}{|c|c|c|c|c|c|c|}
\hline \multirow{2}{*}{ Model } & \multicolumn{2}{|c|}{$\begin{array}{c}\text { Unstandardized } \\
\text { Coefficients }\end{array}$} & $\begin{array}{c}\text { Standardized } \\
\text { Coefficients }\end{array}$ & t & Sig. & VIF \\
\cline { 2 - 7 } & $\mathrm{B}$ & Std.Error & Beta & & & \\
\hline (Constant) & .690 & .173 & & 4.272 & .000 & \\
\hline Irritation & .218 & .046 & .340 & 5.125 & .000 & 1.575 \\
\hline
\end{tabular}

It is important to point out the $t$ value in the table. There is a very strong relationship $(t=5.125)$ what gives a red signal to companies and marketers. It is very logical that irritation may influence the consumer behavior in negative way.

Table 5: Multiple Regression Analysis Related to Utility toward Attitude

\begin{tabular}{|c|c|r|r|c|c|c|}
\hline \multirow{2}{*}{ Model } & \multicolumn{2}{|c|}{$\begin{array}{c}\text { Unstandardized } \\
\text { Coefficients }\end{array}$} & $\begin{array}{c}\text { Standardized } \\
\text { Coefficients }\end{array}$ & t & Sig. & VIF \\
\cline { 2 - 5 } & \multicolumn{1}{|c|}{$\mathrm{B}$} & Std.Error & Beta & & & \\
\hline (Constant) & .498 & .176 & & 2.825 & .005 & \\
\hline Utility & .242 & .043 & .363 & 5.531 & .000 & 1.271 \\
\hline
\end{tabular}

This table represents two items related to Utility. There is no doubt about meaningful relationship between these two variables determing general attitude $(p=.000, t=5.531)$. These results can be also be related to population grooup which was tested, knowing that young population is very familiar with mobile tools and forms.

The following table presents data obtained by analyzing items related to Personalization and their impact on the general attitude of consumers of mobile marketing.

Table 6: Multiple Regression Analysis Related to Personalization toward Attitude

\begin{tabular}{|c|c|r|r|c|c|c|}
\hline \multirow{2}{*}{ Model } & \multicolumn{2}{|c|}{$\begin{array}{c}\text { Unstandardized } \\
\text { Coefficients }\end{array}$} & $\begin{array}{c}\text { Standardized } \\
\text { Coefficients }\end{array}$ & t & Sig. & VIF \\
\cline { 2 - 7 } & \multicolumn{1}{|c|}{$\mathrm{B}$} & Std.Error & Beta & & & \\
\hline (Constant) & .721 & .230 & & 3.135 & .002 & \\
\hline Personalization & .230 & .047 & .326 & 4.903 & .000 & 1.023 \\
\hline
\end{tabular}


From the table it can be concluded that users really expect personalized content, and that their attitude will be more positive if the content is more adapted to the user. Table 7 shows how frequency of receiving mobile ads influence general attitude.

Table 7: Multiple Regression Analysis Related to Frequency toward Attitude

\begin{tabular}{|c|c|c|c|c|c|c|}
\hline \multirow[t]{2}{*}{ Model } & \multicolumn{2}{|c|}{$\begin{array}{l}\text { Unstandardized } \\
\text { Coefficients }\end{array}$} & \multirow{2}{*}{$\begin{array}{c}\text { Standardized } \\
\text { Coefficients } \\
\text { Beta }\end{array}$} & \multirow[t]{2}{*}{$\mathbf{t}$} & \multirow[t]{2}{*}{ Sig. } & \multirow[t]{2}{*}{ VIF } \\
\hline & B & Std.Error & & & & \\
\hline (Constant) & 3.102 & .184 & & 16.855 & .000 & \\
\hline $\begin{array}{c}\text { Frequency of receiving } \\
\text { mob ads }\end{array}$ & -.236 & .058 & -.296 & -4.095 & .000 & 1.000 \\
\hline
\end{tabular}

Since in this case we have a negative value of B and Beta, we can immediately conclude that there is a negative relationship between the variables. This factor can be associated with irritation, because too many ads from one consumer may cause a negative attitude about the same. Companies should be very careful about this factor. The final table in this section presents Multiple Regression Analysis related to General Attitudes toward Response Behavior. In this case, General Attitude is independent variable, while Response Behavior is dependent variable.

Table 8: Multiple Regression Analysis Related to Attitudes toward Response Behavior

\begin{tabular}{|c|r|r|r|r|r|c|}
\hline \multirow{2}{*}{ Model } & \multicolumn{2}{|c|}{$\begin{array}{l}\text { Unstandardized } \\
\text { Coefficients }\end{array}$} & $\begin{array}{c}\text { Standardized } \\
\text { Coefficients }\end{array}$ & \multirow{2}{*}{ t } & \multirow{2}{*}{ Sig. } & VIF \\
\cline { 2 - 6 } & \multicolumn{1}{|c|}{$\mathrm{B}$} & Std.Error & \multicolumn{1}{|c|}{ Beta } & & & \\
\hline (Constant) & 1.953 & .271 & & 7.276 & .000 & \\
\hline Attitude & .584 & .109 & .373 & 5.332 & .000 & 1.000 \\
& & & & & & \\
\hline
\end{tabular}

\section{Conclusion}

Based on analysis and findings, variables of content have different effect on consumer attitude. According to the result of multiple regression analysis we may also know that when consumers express their attitude toward mobile marketing, they evaluate the information and entertainment that they perceived from the advertising material and then define their attitudes accordingly. In view of the above factors, to improve consumer's mobile marketing attitude the mobile marketing managers should never forget the following proposals when implementing mobile marketing. Firstly, the mobile marketing managers of companies should respect consumers completely through getting permission of sending mobile advertisement to consumers and to compete with other companies of the same industry, incentive is the most effective instrument. At the same time, the company should implement different advertising strategies for high and low involvement consumer groups to increase the involvement of all consumers. Besides, different forms of advertisement provide product information in different degrees. On the other hand, if a consumer shops using mobile marketing, company should provide the convenient, benefit or discount promised in the mobile advertisement to give the consumer a satisfactory experience. All the above mentioned categories are for the improvement of consumer's perceived advertising value and attitude toward mobile marketing.

\section{Limitations and Future Research}

Even if young population is faster adopter of new technology than adults the main restriction of this research has been pointed that young population is not homogeneous audiences for mobile 
phones because of social background, gender, urban/rural lifestyles, and technological literacy can widely vary. Future researches relevant to the mobile marketing topics should address this issue along with the moderating role of gender because gender-related aspects can affect attitudes toward mobile marketing (Karjaluotoet, 2008). Future research can also be expanded by factors like intrusiveness and perceived control which are similar to irritation; additionally it could analyze the role of such factors on consumer attitudes and behavior towards mobile advertising on bigger sample and with more items per factor in survey. A recommendation is also to conduct empirical research with a important focus on demographics, using a representative sample of the population of multiple countries to map the differences.

\section{References:}

Agencija za statistiku BiH, (2014). Retreived March 2014 from http://www.bhas.ba

Bauer, H.H., Reichardt, T., Barnes, S.J., \& Neumann, M.M.. (2005). Driving consumer acceptance of mobile marketing: a theoretical framework and empirical study. Journal of Electronic Commerce Research, 6(3), pp. 181-191.

Cronbach, L.J. (1951). Coefficient alpha and the internal structure of tests. Psychometrika, Vol. 16, pp. 297-334.

Ducoffe, R.H. (1996). Advertising value and advertising on the web. Journal of Advertising Research, Vol. 36 No. 5, pp. 21-35.

Gao, T. T., Sultan, F., \& Rohm, A. J. (2010). Factors influencing Chinese youth consumers' acceptance of mobile marketing. Journal of Consumer Marketing, 27(7), 574-583.

Haghirian P., Madlberger M.., Tanuskova A., (2005). Increasing Advertising Value of Mobile Marketing -An Empirical Study of Antecedents, 38th Hawaii International Conference on System Sciences, p. 32

Jayawardhena, C., Kuckertz, A., Karjaluoto, H., \& Kautonen, T. (2009). Antecedents to permission based mobile marketing: an initial examination. European Journal of Marketing, 43(3/4), pp. 473-499.

Karjaluoto, H., Lehto, H., Leppa“niemi, M. and Jayawardhena, C. (2008). Exploring gender influence on customer's intention to engage permission-based mobile marketing, Electronic Markets, Vol. 18 No. 3, pp. 242-259

Levi, S. (1990). Values and Deeds. Applied Psychology: An Interactional Review, 39 (4), pp. 379-400.

MacKenzie, Scott B. (1989). The Role of Attitude Toward the Ad as a Mediator of Advertising Effectiveness: A Test of Competing Explanations. Journal of Marketing Research, Vol. XXIII, 130-43.

Nunnaly, J.C (1978). Psyhometric Theory (2.Ed), New York: McGraw-Hill.

Parreño, J. M. (2013). Key factors of teenagers' mobile advertising acceptance. Industrial Management \& Data Systems, 113(5), 732-749. doi:10.1108/02635571311324179

Persaud, A., \& Azhar, I. (2012). Innovative mobile marketing via smartphones: Are consumers ready? Marketing Intelligence \& Planning, 30(4), 418-443. doi:10.1108/02634501211231883

Roach, G. (2009). Consumer perceptions of mobile phone marketing: a direct marketing innovation, Direct Marketing: An international Journal, Vol. 3, Iss: 2, pp. 124-138 
Robins, F. (2003). The Marketing of 3 G: Marketing Intelligence \& Planning, pp. 370-378.

Smutkupt, P., Krairit, D., \& Khang, D. B. (2012). Mobile marketing and consumer perceptions of brand equity. Asia Pacific Journal of Marketing and Logistics, 24(4), 539-560. doi:10.1108/13555851211259016

Taylor Charles R., Okazaki S. (2008). What is SMS advertising and why do multinationals adopt it? Answers from an empirical study in European markets, Journal of Business Research, Vol. 61, pp. 4-16 